\title{
Cold Urticaria
}

\author{
RECOGNITION AND CHARACTERIZATION OF A NEUTROPHIL \\ CHEMOTACTIC FACTOR WHICH APPEARS IN SERUM DURING \\ EXPERIMENTAL COLD CHALLENGE
}

\author{
Stephen I. Wasserman, Nicholas A. Soter, David M. Center, and K. Frank Austen \\ From the Departments of Medicine and Dermatology, Harvard Medical School and the \\ Divisions of Dermatology, Departments of Medicine, Robert B. Brigham and \\ Peter Bent Brigham Hospitals, Boston, Massachusetts 02120
}

\begin{abstract}
A B S T R A C T Sera were obtained from the venous effluents of cold-challenged arms of patients with idiopathic cold urticaria without plasma or serum cryoproteins; these sera exhibited increased neutrophil chemotactic activity without alterations of the complement system. A two- to fourfold augmentation of the base-line neutrophil chemotactic activity of serum from the immersed extremity began within 1 min, peaked at $2 \mathrm{~min}$, and returned to base-line levels within 15 min, whereas there was no change in the serum chemotactic activity in the control arm. The augmented chemotactic activity in the serum specimens from the challenged arm of each patient appeared in a high molecular-weight region, as assessed by the difference in activity recovered after Sephadex G-200 gel filtration of the paired lesional and control specimens. Sequential purification of "this high molecular-weight activity by anion- and cation-exchange chromatography revealed a single peak of activity at both steps. The partially purified material continued to exhibit a high molecular weight, being excluded on Sepharose 4B, and had a neutral isoelectric point. The partially purified material showed a preferential chemotactic activity for neutrophilic polymorphonuclear leukocytes, required a gradient for expression of this function, and exhibited a capacity to deactivate this cell type. This
\end{abstract}

Dr. Wasserman is a Fellow of the Arthritis Foundation. Dr. Soter is the recipient of National Research Service Award 1F32 AI 05240, and Dr. Center is supported by training grant AM 58721, both from the National Institutes of Health.

Received for publication 17 January 1977 and in revised form 7 March 1977. active principle, termed high molecular-weight neutrophil chemotactic factor, exhibited a time-course of release that could be superimposed upon that of histamine and the low molecular-weight eosinophil chemotactic factor and may represent another mast cellderived mediator.

\section{INTRODUCTION}

Idiopathically acquired, cold-induced urticaria is a disorder in which patients, when exposed to cold, experience an urticarial eruption that may evolve into angioedema and is rarely associated with syncope or wheezing. A substantial number of these patients possess a serum factor capable of transferring cold urticaria to a skin site of a normal recipient as assessed by local cold challenge $24 \mathrm{~h}$ later (1). Isolation and immunochemical characterization of the principle involved in passive transfer have shown that it is IgE (2). Participation of the mast cell in the clinical entity is suggested by the involvement of IgE and by the recognition of histamine in whole blood, plasma, or serum (3-7) after the challenge of patients with local cold. Further evidence for involvement of the mast cell is derived from finding a low molecular-weight eosinophil chemotactic factor, comparable in size to the eosinophil chemotactic factor of anaphylaxis, in the venous effluent from an arm of the affected patient after cold immersion (7). During the characterization of the eosinophil chemotactic activity in the serum, an additional chemotactic principle with specificity for neutrophils is noted. This neutrophil chemotactic factor has a high molecular weight and a neutral isoelectric point. 


\section{METHODS}

Phenol red (Sigma Chemical Co., St. Louis, Mo.), Hanks' balanced salt solution (HBSS) ${ }^{1}$ and Medium 199 (Microbiological Associates, Bethesda, Md.), Sephadex G-200, Sepharose 4B, Ficoll, quaternary amino ethyl (QAE)-Sephadex, blue dextran, and sulfopropyl (SP)-Sephadex (Pharmacia Fine Chemicals, Div. of Pharmacia, Inc., Piscataway, N. J.), ovalbumin (Miles Laboratories, Kankakee, Ill.), Hypaque (diatrizoate, Winthrop Laboratories Inc., Miles Research Products, New York), and Ampholine carrier ampholytes (LKB Instruments, Inc., Rockville, Md.) were obtained from the manufacturers.

Seven patients with idiopathically acquired, coldinduced urticaria participated in a protocol, after giving informed consent, in which one arm was immersed in ice water up to the antecubital fossa for $3 \mathrm{~min}$, while the control arm remained at room temperature. Indwelling intravenous needles were placed in both arms at the level of the antecubital fossae, and blood was obtained from both just before and serially at $0.5,2,5,10,15,30$, and $60 \mathrm{~min}$ after immersion of one arm. Blood was collected into plastic tubes and allowed to clot for $60 \mathrm{~min}$ at $4^{\circ} \mathrm{C}$; serum was separated by centrifugation at $800 \mathrm{~g}$ for $15 \mathrm{~min}$ in the cold, divided into aliquots and stored at $-70^{\circ} \mathrm{C}$ for subsequent analyses. Challenge of two normal laboratory volunteers was performed in an identical fashion.

Whole serum complement activity determinations $\left(\mathrm{CH}_{50}\right)$ (8), effective molecule titrations for C1 (9), C4 (10), C2 (11), C3 (12), and C9 (13), and immunochemical measurements (14) of Clq (15), C4 (16), C3 (15), C5 (17), B (18), properdin (19), and the CI inhibitor (20) were conducted as described. For assessment of cryoproteins, blood was drawn into plastic syringes at $37^{\circ} \mathrm{C}$, distributed into glass tubes with and without disodium EDTA, clotted for $1 \mathrm{~h}$ at $37^{\circ} \mathrm{C}$, and sedimented at the same temperature. The cryocrits of the serum and the plasma were determined in calibrated tubes that were maintained at $4^{\circ} \mathrm{C}$ for $24 \mathrm{~h}$ and then centrifuged at $250 \mathrm{~g}$ for 10 min at $4^{\circ} \mathrm{C}(21)$.

Chemotaxis. In order to obtain leukocytes for chemotaxis, 6-ml portions of venous blood from normal donors and from a patient with hypereosinophilia of $35 \%$ were incubated with 1 $\mathrm{ml}$ dextran and $0.75 \mathrm{ml}$ citrate anticoagulant, $\mathrm{pH} 5.2$, for $45 \mathrm{~min}$ at $37^{\circ} \mathrm{C}$ to allow sedimentation of the erythrocytes. The leukocyte-rich supernatant fraction was aspirated and suspended in $0.84 \% \mathrm{NH}_{4} \mathrm{Cl}$ to lyse contaminating erythrocytes. The leukocytes then were sedimented at $400 \mathrm{~g}$ for $10 \mathrm{~min}$ at room temperature, washed twice in HBSS containing $0.4 \%$ ovalbumin and $0.005 \mathrm{M}$ Tris, $\mathrm{pH} 7.4$, and resuspended at a concentration of 2.4-2.8 $\times 10^{6} / \mathrm{ml}$ in Medium 199 made $0.4 \%$ with ovalbumin and $0.005 \mathrm{M}$ Tris, pH 7.4. In some experiments the cells were separated into polymorphonuclear leukocyte- and mononuclear leukocyterich fractions by centrifugation upon Hypaque-Ficoll cushions (22).

Chemotaxis was assessed by a modification (23) of the Boyden chamber assay (24) with 2.4-2.8 $\times 10^{6}$ cells separated from the chemotactic stimulus or buffer by micropore filters (Millipore Corp., Bedford, Mass.) fixed to polystyrene disposable chemotactic chambers (Adaps Corp., Dedham, Mass.). $3-\mu \mathrm{m}$ pore size micropore filters were employed for chemotactic studies of neutrophilic and eosinophilic polymorphonuclear leukocytes, and 5- $\mu \mathrm{m}$ pore size filters were used for

${ }^{1}$ Abbreviations used in this paper: HBSS, Hanks' balanced salt solution; hpf, high power field(s); QAE-Sephadex, quaternary amino ethyl-Sephadex; SP-Sephadex, sulfopropylSephadex. mononuclear leukocytes. The lower compartment was filled with $1 \mathrm{ml}$ of buffer alone or of material being assessed for chemotactic activity. Chemotaxis was carried out for 2.5$3 \mathrm{~h}$ at $37^{\circ} \mathrm{C}$ in moist chambers; the cell response was determined by counting the cells at a fixed distance into the stained filter. This distance was selected to achieve background counts in the absence of a chemotactic stimulus of zero to six cells for mixed leukocytes or for neutrophilic and eosinophilic leukocytes and zero to four cells for mononuclear leukocytes. Cells then were counted without knowledge of the protocol in 5 high power fields (hpf) from each of duplicate filters, and these values were expressed as the mean net cells per high power field per milliliters of chemotactic factor by correction for spontaneous migration in additional controls. The mean values of the duplicate filters differed by $<10 \%$.

Deactivation refers to the failure of leukocytes to migrate along a concentration gradient of a chemotactic stimulus as a result of a previous interaction with an active chemotactic factor (25). The deactivation reaction has the same specificity as chemotactic activation but differs in that the concentrations of factors interacting with target cells are defined because a gradient is not involved. The degree of deactivation was determined by comparing the migration of cells pretreated with a chemotactic factor with the migration of untreated cells in response to identical chemotactic gradients. The net response of treated and untreated cells was quantitated as described for routine chemotactic experiments, and the percent deactivation was calculated by $(1-$ [net response of deactivated cells]/[net response of buffer treated cells]) $\times 100$.

Isoelectric focusing. Isoelectric focusing was performed both in a sucrose density gradient column and in a thin layer of Sephadex G-75 gel. A 15-ml linear 10-40\% sucrose gradient containing $2 \% \mathrm{vol} / \mathrm{vol}$ ampholytes, $\mathrm{pH} 3-10$, was prepared in a glass column (Metaloglass, Boston, Mass.) at room temperature with a gradient maker (Buchler Instruments Div., Seale Analytic Inc., Ft. Lee, N. J.). $1 \mathrm{ml}$ of sample was mixed with the $40 \%$ sucrose in the well of the gradient maker after $1 \mathrm{ml}$ of the gradient had been generated and was subsequently dispersed throughout the entire gradient. Isoelectric focusing was performed at a constant $800 \mathrm{~V}$ at $10^{\circ} \mathrm{C}$ until the current dropped to $2 \mathrm{~mA}$. The gradient was decanted in $0.5-\mathrm{ml}$ portions, and the $\mathrm{pH}$ of each portion was measured. The fractions were then dialyzed overnight at $4^{\circ} \mathrm{C}$ against 1 liter of HBSS and assessed for their chemotactic activity.

A $20 \times 20$-cm thin-layer plate was filled with a suspension of $200 \mathrm{ml}$ Sephadex G-75 in distilled water containing $1.25 \%$

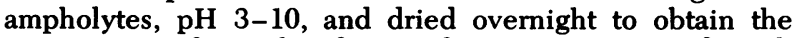
consistency of a gel. After prefocusing at $400 \mathrm{~V}$ for $6 \mathrm{~h}$ in a Brinkmann/Desaga double-chamber apparatus (Brinkmann Instruments, Inc., Westbury, N. Y.), $1 \mathrm{ml}$ of sample was applied to the center of the gel; and the gel was subjected to $500 \mathrm{~V}$ for $6 \mathrm{~h}$ at $10^{\circ} \mathrm{C}$. The gel was then sectioned into 20 equal fractions; the $\mathrm{pH}$ of each fraction was measured; and the fractions were diluted in $10 \mathrm{ml}$ of HBSS and centrifuged at $1,000 \mathrm{~g}$ for $10 \mathrm{~min}$ at room temperature. The supernatant fractions were decanted, and the pellets were resuspended in the same buffer and sedimented twice more. The three supernatant fractions from each of the 20 gel slices were combined, concentrated, dialyzed against $400 \mathrm{vol}$ of HBSS for $48 \mathrm{~h}$ at $4^{\circ} \mathrm{C}$, and assessed for chemotactic activity.

\section{RESULTS}

Appearance of neutrophil chemotactic activity in serum of patients with cold urticaria upon cold 


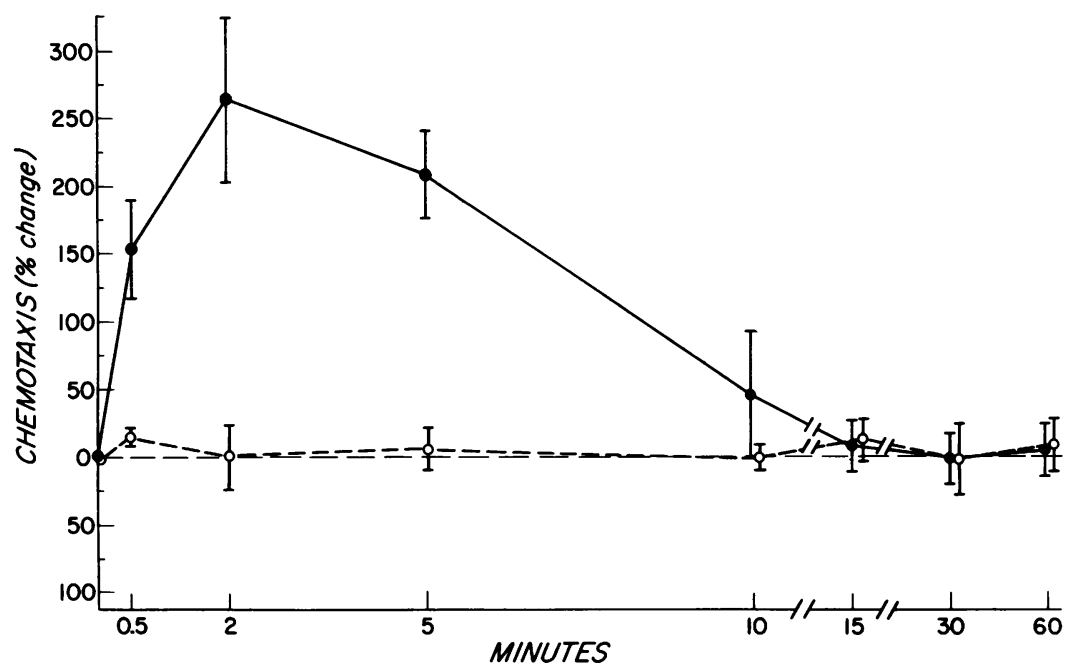

FIgURE 1 Time-course of appearance of neutrophil chemotactic activity obtained from venous effluent sera from seven patients after experimental cold challenge. Each point represents the mean $( \pm 1$ SD) net percent change in the neutrophil chemotactic activity in lesional (O) and control arms $(\mathrm{O})$, as compared to time zero.

challenge. The seven patients with cold-induced urticaria noted pain that lasted $60-90 \mathrm{~s}$ followed by warmth and pruritus in the immersed extremity. Erythema was noted at the time that the immersed extremity was withdrawn from the ice water, and urticaria and angioedema developed over the next 4-6 min. Urticarial lesions were apparent on the arm at and just below the level of immersion, while the remainder of the extremity was diffusely enlarged with nonpitting edema. Urticarial streaks with erythema overlying veins developed above the point of immersion. No lesions appeared on the control arm. Normal subjects experienced only pain followed by numbness during immersion and did not develop urticaria or angioedema.

Paired serum specimens obtained from the cold-challenged and control arms of each of the seven patients showed comparable base-line levels of neutrophil chemotactic activity at time zero. Increased chemotactic activity appeared in the venous effluent of the coldchallenged extremity within $30 \mathrm{~s}$, reached a peak at 2 min, and returned to base-line levels within approximately $15 \mathrm{~min}$ (Fig. 1). The base-line chemotactic activity at time zero assayed with different target cell pools for each of the seven patients ranged from 52 to 170 cells/hpf per $\mathrm{ml}$, and the net chemotactic activity in the 2 -min samples ranged from 125 to 700 cells/hpf per $\mathrm{ml}$. Normal individuals subjected to cold immersion did not develop augmented chemotactic activity in the venous effluent of the challenged extremity at any time.

Paired 1.5-ml control and lesional serum samples from four of the seven patients $(A, C, D, Z)$ were studied further by separate application to a $1.5 \times 90-\mathrm{cm}$ column of Sephadex G-200 equilibrated in HBSS and run at $4^{\circ} \mathrm{C}$ with a flow rate of $10 \mathrm{ml} / \mathrm{h}$. 2-ml fractions were collected, and 100- $\mu$ l aliquots of alternate fractions were assessed for chemotactic activity. Sera from the control arms showed three areas of chemotactic activity at 35,45 , and $75 \%$ bed volume, as illustrated for patient $C$ (Fig. 2). The sera obtained from the challenged arms of four patients $(A, C, D, Z)$ differed in that the peak of chemotactic activity that filtered at the void volume was greatly augmented, as represented by patient $\mathrm{C}$ (Fig. 2), and ranged from 75 to 160 cells/hpf per $\mathrm{ml}$ for peak tubes, as compared to base-line values from 26 to 42 cells/hpf per $\mathrm{ml}$. Patient $\mathrm{Z}$ also

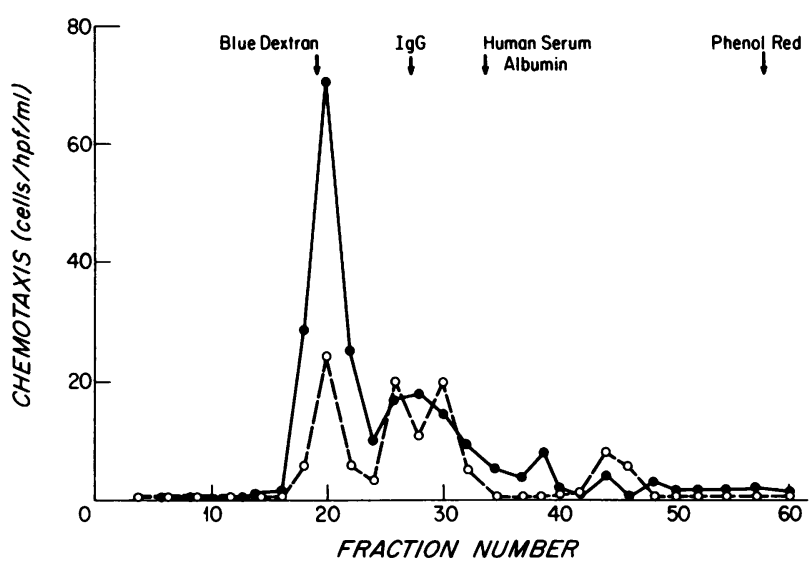

FIGURE 2 Neutrophil chemotactic activity after Sephadex G-200 chromatography of serum from cold-challenged (๑) and control $(O)$ arms of patient $C$. Neutrophil chemotactic activity is depicted as net leukocytes per high power field per milliliter in each column fraction. 


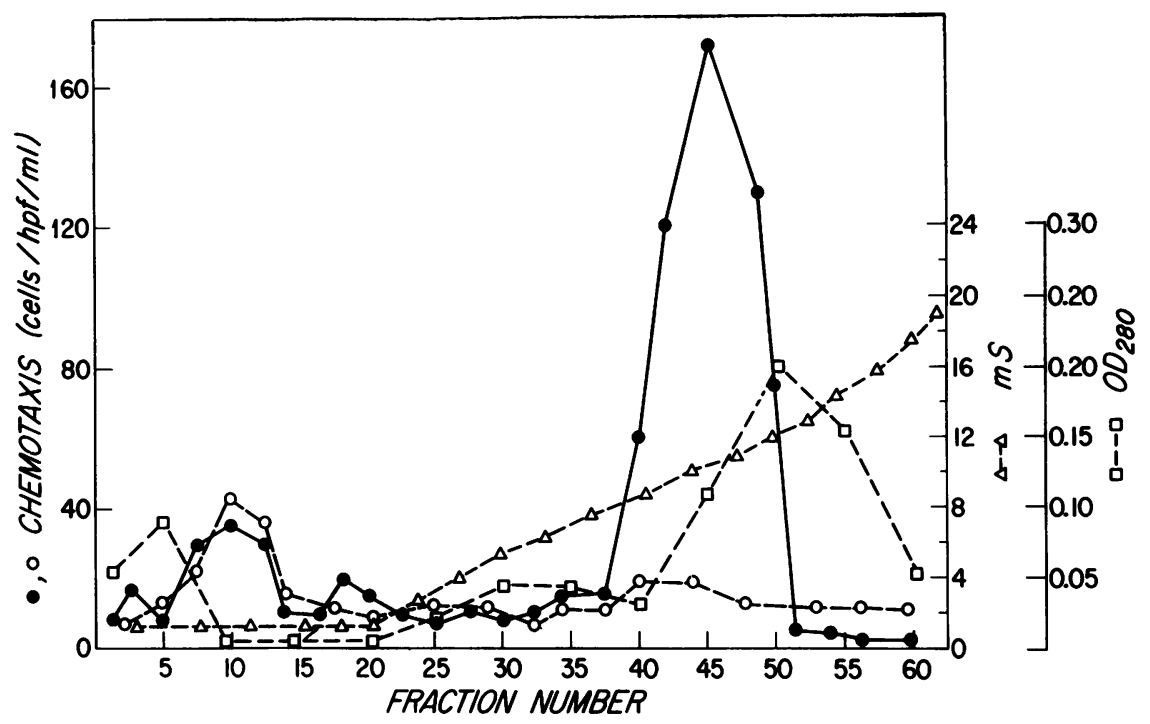

FIGURE 3 QAE-Sephadex chromatography of high molecular-weight neutrophil chemotactic activity obtained from exclusion volume of Sephadex G-200 gel filtration of serum from coldchallenged $(O)$ and control $(O)$ arms of patient $C$. Protein estimated by optical density at $280 \mathrm{~nm}$ $(\square)$ and salt gradient in $\mathrm{mS}(\Delta)$ are presented for the lesional arm only but were not significantly different in the control specimens.

demonstrated augmented chemotactic activity in the region of $45 \%$ bed volume; but inasmuch as this difference was not noted in the other three patients, only the augmented chemotactic activity in the void volume was further characterized.

The complement system was assessed in terms of C1, C4, C2, C3, and C9 functional activity and Clq, C4, C3, C5, B, properdin, and Cì inhibitor protein concentrations. No differences were found between the normal and challenged extremities nor were there alterations from the base-line values.

Partial purification and physical characterization of the high molecular-weight neutrophil chemotactic factor. The high molecular-weight peak of chemotactic activity found after Sephadex G-200 chromatography of serum from the lesional arm was further isolated and characterized in patients $A, C$, and $Z$. The fractions in the void volume of Sephadex G-200 chromatography of the 2-min specimens from both the lesional and control arms were separately pooled and dialyzed at $4^{\circ} \mathrm{C}$ overnight against one change of $200 \mathrm{vol}$ of $0.0035 \mathrm{M}$ phosphate buffer, $\mathrm{pH}$ 7.8. The dialyzed material was concentrated by ultrafiltration to $10 \mathrm{ml}$ (Amicon Corp., Scientific Sys. Div., Lexington, Mass.) and applied to a $0.9 \times 30-\mathrm{cm}$ column of QAE-Sephadex equilibrated in the dialysis buffer. The column was washed with 10 bed volumes of the same buffer and eluted at $4^{\circ} \mathrm{C}$ with a linear salt gradient of $400 \mathrm{ml}$ to $0.5 \mathrm{M} \mathrm{NaCl}$. 4-ml fractions were obtained, and $250-\mu \mathrm{l}$ aliquots of alternate fractions were assessed for chemotactic activity. An increased peak of chemotactic activity in sera from the lesional, as compared to the control arm, eluted between 6 and $12 \mathrm{mS}$ in all three patients, as illustrated for patient $\mathrm{C}$ (Fig. 3). Because of minimal activity, fractions from the control extremities were not further purified.

Fractions eluting between 6 and $12 \mathrm{mS}$ from the lesional arms of all three patients were separately pooled, concentrated to $4 \mathrm{ml}$, and dialyzed against $200 \mathrm{vol}$ of $0.01 \mathrm{M}$ acetate buffer, pH 6.0, overnight at $4^{\circ} \mathrm{C}$ with one change of dialysis buffer. The dialyzed material was applied to an SP-Sephadex column of 20-ml bed volume, which was equilibrated and then washed with 5 bed volumes of the same buffer. Elution was carried out at $4^{\circ} \mathrm{C}$ with a 300 -ml linear salt gradient to $0.4 \mathrm{M} \mathrm{NaCl}$; 4-ml fractions were collected and $250-\mu \mathrm{l}$ aliquots were assessed for chemotactic activity. A single peak of chemotactic activity was found in the effluent in all patients, as illustrated for patient $C$ (Fig. 4).

The effluent fractions containing chemotactic activity designated as partially purified high molecular-weight neutrophil chemotactic factor were pooled, concentrated to $6.0 \mathrm{ml}$, and dialyzed overnight at $4^{\circ} \mathrm{C}$ against 1 liter of HBSS. $1 \mathrm{ml}$ of material from patient $C$ was dialyzed overnight at $4^{\circ} \mathrm{C}$ against distilled water and subjected to isoelectric focusing in sucrose, and $1 \mathrm{ml}$ of material from patient $\mathrm{Z}$ was similarly dialyzed against distilled water and was focused in thin-layer Sephadex G-75 plates. Neutrophil chemotactic activity appeared in a single peak that focused between $\mathrm{pH} 6.7$ and 7.4 in sucrose (Fig. $5 a$ ) and between pH 6.8 and 7.4 in Sephadex G-75 plates (Fig. $5 b$ ). Thus, in both patients when wide-range ampholytes were used, the iso- 
electric point of the high molecular-weight neutrophil chemotactic factor was in a neutral range. Further, in no instance was sufficient heterogeneity observed to suggest that the partially purified material contained more than one major active principle.

The size of the high molecular-weight neutrophil chemotactic factor obtained at the isoelectric focusing step of serum from patient $Z$ and the effluent from SPSephadex chromatography from patient $C$ was determined on Sepharose 4B. $1 \mathrm{ml}$ of material obtained after a sixfold concentration of the peak fraction from isoelectric focusing, and $1 \mathrm{ml}$ of concentrated effluent from SP-Sephadex were each applied to a $1.5 \times 90$ cm column of Sepharose 4B equilibrated in HBSS and calibrated with dextran blue and phenol red. The columns were run at flow rates of $8 \mathrm{ml} / \mathrm{h}, 2.5-\mathrm{ml} \mathrm{frac-}$ tions were collected, and 200- $\mu \mathrm{l}$ aliquots of consecutive fractions were assessed for neutrophil chemotactic activity. The chemotactic activity was excluded, indicating a molecular weight in excess of 750,000 , as illustrated for patient $\mathrm{C}$ (Fig. 6).

Functional characterization of partially purified high molecular-weight neutrophil chemotactic activity. Although the chemotactic activity that appeared in serum as a result of cold challenge was assessed throughout with the mixed leukocytes of normal donors, the predominant responding cell type was the neutrophil. To define the range of chemotactic activity of the factor purified through SP-Sephadex from patient $\mathrm{C}$ and isoelectric focusing in patient $\mathrm{Z}$, the response of neutrophilic, eosinophilic, and mononuclear leukocytes was compared. A doseresponse relationship was obtained between the concentration of chemotactic factor and the number of responding neutrophils with a plateau as illustrated with material obtained from patient $C$ (Fig. 7). The response of mononuclear leukocytes was observed only at the highest dose. There was no neutrophil migra-

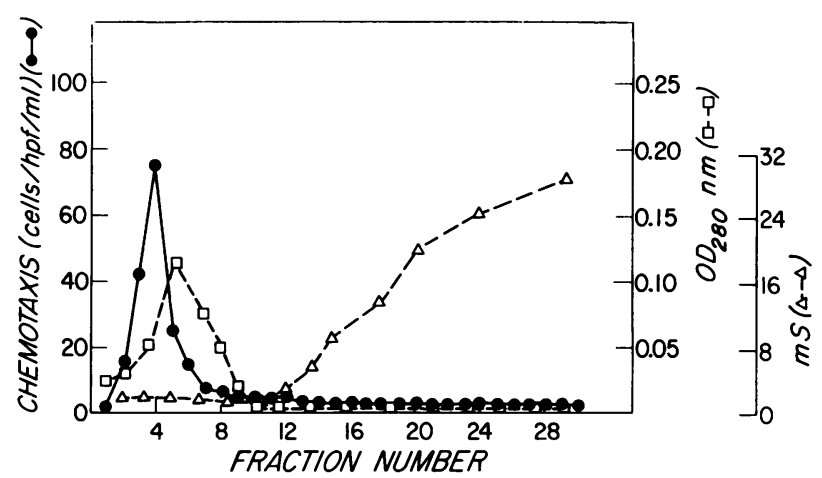

FIGURE 4 SP-Sephadex chromatography of neutrophil chemotactic activity eluting between 6 and $12 \mathrm{mS}(0)$ from QAE-Sephadex in patient $C$. The protein estimated by optical density at $280 \mathrm{~nm}$ is depicted by $(\square)$ and salt gradient by $(\triangle)$.

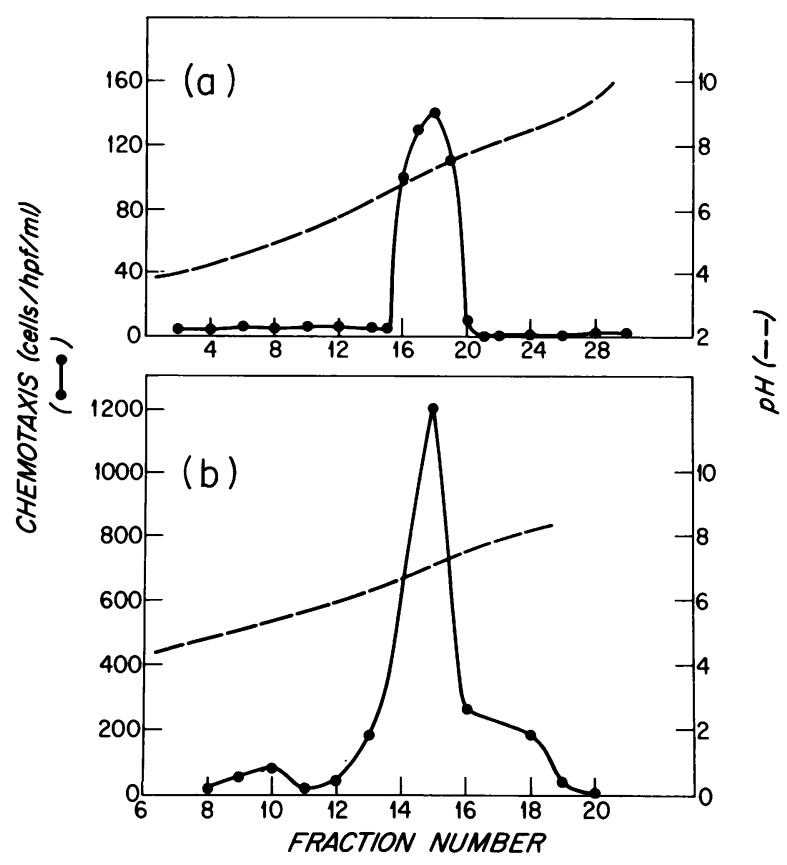

FIGURE 5 (a) Isoelectric focusing in sucrose of partially purified high molecular-weight neutrophil chemotactic activity obtained from patient C. (b) Isoelectric focusing in thin-layer Sephadex G-75 gel of high molecular-weight neutrophil chemotactic activity obtained from patient $\mathrm{Z}$.

tion when the gradients were eliminated (Fig. 7). Thus, the purified high molecular-weight principle is a chemotactic factor with a preferential specificity for neutrophilic over mononuclear leukocytes.

The material obtained from patient $\mathrm{Z}$ and further purified by isoelectric focusing was used to compare the response of eosinophilic and neutrophilic leukocytes from a single donor whose peripheral blood contained $35 \%$ eosinophils and $50 \%$ neutrophils.

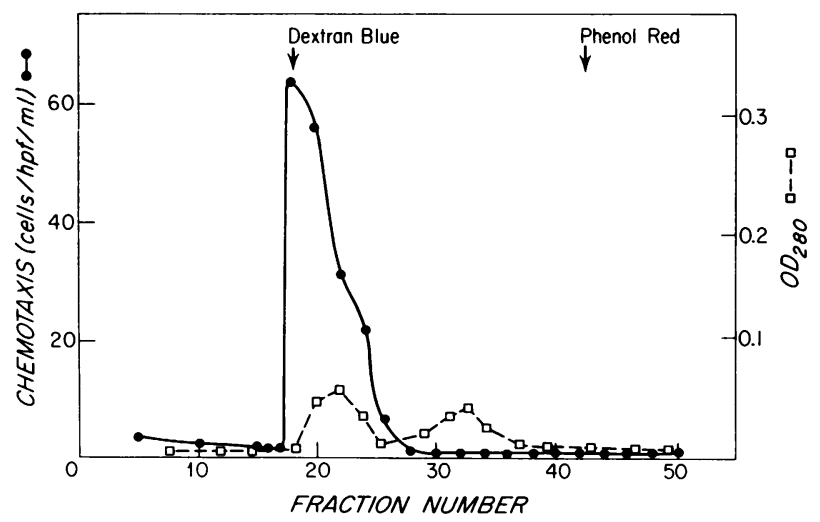

FIGURE 6 Sepharose 4B chromatography of purified neutrophil chemotactic activity (O) in the effluent from SPSephadex chromatography in patient $\mathrm{C}$. Protein is estimated as optical density at $280 \mathrm{~nm}(\square)$. 


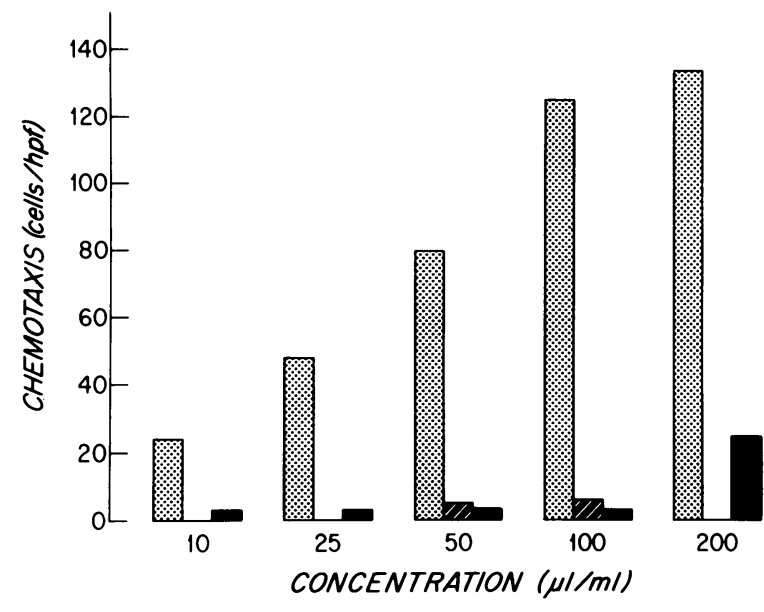

FIgURE 7 Chemotactic responses of neutrophils and mononuclear leukocytes to the purified chemotactic factor from patient C. Neutrophil (stippled bars) chemotaxis was assessed with a cell pool purified to contain more than $95 \%$ neutrophils, while the mononuclear leukocyte response (closed bars) was assessed with a cell pool purified to contain $95 \%$ mononuclear leukocytes. The effect of eliminating the gradient for neutrophils by placement of equal amounts of purified chemotactic factor into both compartments of the chemotactic chamber is depicted by hatched bars.

Each cell type responded in a dose-response fashion. The maximum net neutrophil response exceeded that of the eosinophils by $2 \frac{1}{2}$-fold and occurred at onequarter the concentration of chemotactic factors required for the maximum eosinophil response.

The time-dependent ability of the factor from patient C (purified through SP-Sephadex chromatography) to deactivate neutrophils was examined at two doses. Isolated neutrophils were incubated with buffer alone or with a subchemotactic $(5 \mu \mathrm{l} / \mathrm{ml})$ or minimally chemotactic $(25 \mu \mathrm{l} / \mathrm{ml})$ amount of purified material from patient $\mathrm{C}$ at room temperature for intervals up to $30 \mathrm{~min}$. The cells were sedimented at $500 \mathrm{~g}$ at room temperature, washed twice in HBSS, and resuspended at 2.6 $\times 10^{6} \mathrm{cells} / \mathrm{ml}$ for assessment of their chemotactic response to $100 \mu \mathrm{l}$ of the same material at $37^{\circ} \mathrm{C}$. The purified high molecular-weight chemotactic activity deactivated the neutrophils in a dose- and timedependent manner (Fig. 8).

\section{DISCUSSION}

A factor chemotactic for neutrophilic polymorphonuclear leukocytes increased in amount in the venous effluent of the cold-immersed extremity as compared with the contralateral control arm in each of seven patients with idiopathically acquired cold-induced urticaria. The neutrophil chemotactic activity in the venous effluent of the challenged extremity was uniformly noted at $30 \mathrm{~s}$, reached a peak at $2 \mathrm{~min}$, and was dissipated after $15 \mathrm{~min}$ (Fig. 1). At time zero there was no difference in base-line neutrophil chemotactic activity between the challenged and control arms, and the chemotactic activity remained at base-line levels in the unchallenged extremity.

Sephadex G-200 gel filtration of the 2-min serum specimens from the lesional and control arms of four patients revealed the major difference between the paired specimens to be consistently the neutrophil chemotactic activity that filtered in the void volume (Fig. 2). This activity was further purified by QAESephadex chromatography (Fig. 3); in each patient the activity from the lesional arm eluted between 6 and $12 \mathrm{mS}$, whereas activity from the control arm was too minimal to define. The high molecular-weight neutrophil chemotactic activity was further purified on SPSephadex chromatography, where it appeared in the effluent (Fig. 4), and by isoelectric focusing (Fig. $5 a, b)$. Although the starting sera, both lesional and control, contained several peaks of chemotactic activity as assessed by Sephadex G-200 gel filtration as noted previously (26), the neutrophil chemotactic activity, which appeared in serum from the lesional arm and was selected because of its exclusion by gel filtration on Sephadex G-200, presented as a single peak on anion- and cation-exchange chromatography and on isoelectric focusing.

The purified high molecular-weight neutrophil chemotactic factor isolated from the lesional arms of two patients exhibited a neutral isoelectric point when focused in two different support media (Fig. 5). The neutral isoelectric point was not a loading artifact, since in both techniques the material moved at least 5 $\mathrm{cm}$ from the loading point. Material purified through the SP-Sephadex step or the isoelectric focusing stage was excluded on Sepharose 4B, indicating a molecular weight in excess of 750,000 (Fig. 6).

The responding cell from the mixed leukocyte source used during isolation of the high molecular-weight

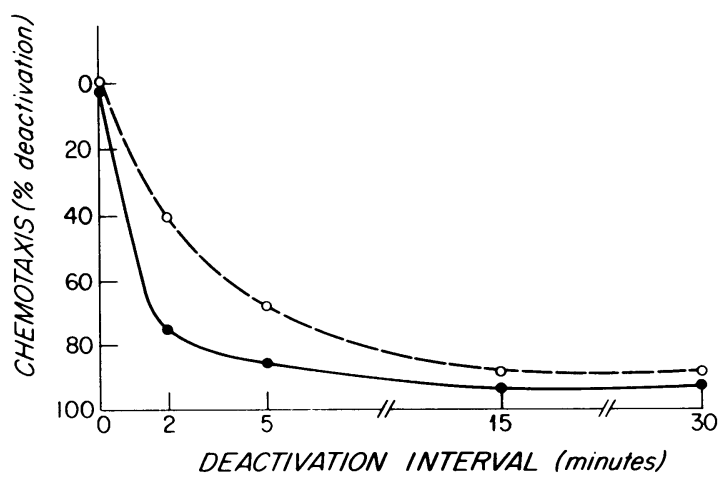

Figure 8 Time-dependent deactivation of neutrophils by 5 (O) or $25(0) \mu$ l of purified chemotactic factor from patient $\mathrm{C}$ as assessed by their subsequent chemotactic response to 100 $\mu l$ of the same stimulus. 
factor was invariably the neutrophil. This point was more clearly demonstrated by the ability of the purified high molecular-weight activity to attract purified neutrophils in a dose-response fashion at concentrations that had little or no effect on mononuclear leukocytes (Fig. 7). The purified high molecular-weight neutrophil chemotactic factor also demonstrated a preference for neutrophils over eosinophils in a doseresponse experiment. The neutrophil response was abrogated if the concentration gradient was abolished by placing identical concentrations of the factor on the cell and stimulus sides (Fig. 7), thus indicating that the activating principle was a chemotactic factor. Chemotactic factors characteristically deactivate their specific target cell in terms of a subsequent chemotactic response to the same or a different chemotactic stimulus (25). Further, studies with the eosinophil chemotactic factor of anaphylaxis have revealed that the concentrations required for deactivation are considerably less than those needed to establish an effective gradient for chemotactic migration $(27,28)$. As illustrated in Fig. 8, the high molecular-weight neutrophil chemotactic factor deactivated neutrophils in a timeand dose-related fashion. The concentrations effective in deactivation were subthreshold to minimal when compared to the chemotactic stimulus utilized to demonstrate that the cells were deactivated.

There is no evidence that the high molecularweight neutrophil chemotactic factor is derived from the activation of the complement system as complement protein concentrations and their specific functional activities were not altered from base-line levels in the lesional or the control sera. The time-course of the appearance of serum chemotactic activity for neutrophils was indistinguishable from that of histamine and of material similar to the eosinophil chemotactic factor of anaphylaxis reported in an earlier study (7), implying, but not establishing, a mast cell origin for this mediator. Chemotactic activity preferential for neutrophils and greater than 30,000 molecular weight has been noted in extracts of human leukemic basophils (29) and lung fragments (30), but this activity has not been further characterized. The appearance of a factor that augmented neutrophil migration in the serum of sensitized asthmatic patients after inhalation challenge with specific antigen has been reported (31), but the active principle has not been characterized physicochemically or functionally. Neutrophils have been observed, along with other cell types, in experimental cutaneous lesions in humans in which the mast cell has been implicated. Thus, in a unique patient with cold- and trauma-induced cutaneous necrotizing venulitis and hypocomplementemia but without cryoglobulins, mast cell degranulation has been observed to precede the ingress of neutrophils into the lesional site (32). Moreover, the delayed cutaneous in- flammatory reaction, mediated by IgE-dependent mechanisms, is characterized not only by mast cell degranulation but also by infiltration of diverse cell types including neutrophils $(33,34)$. These observations suggest that the mast cell may be involved in neutrophil chemotaxis. The recognition of high molecular-weight neutrophil chemotactic factor in cold urticaria, an IgE-mast cell-dependent disease, provides a mechanism by which the mast cell may affect the responsiveness of neutrophils and thereby modulate neutrophil-dependent inflammatory events.

\section{ACKNOWLEDGMENTS}

The authors wish to acknowledge the expert technical assistance of Ms. Susan MacDonald Lynch, Ms. Eileen Willcox, and Ms. Mary Riley. The authors thank Dr. Albert L. Sheffer for referring patients and Dr. Peter $\mathrm{H}$. Schur for performing the immunochemical measurements of complement proteins.

This work was supported by grants AI 07722, AI 10356, AM 05577, HL 17382, and RR 05669 from the National Institutes of Health of the U. S. Public Health Service.

\section{REFERENCES}

1. Sherman, W. B., and P. M. Seebohm. 1950. Passive transfer of cold urticaria. J. Allergy. 21: 414-424.

2. Houser, D. D., C. E. Arbesman, K. Ito, and K. Wicher. 1970. Cold urticaria. Immunologic studies. Am.J. Med. 49: 23-33.

3. Rose, B. 1941. Studies on blood histamine in cases of allergy. I. Blood histamine during wheal formation. J. Allergy. 12: 327-334.

4. Rose, B. 1954. Histamine, hormones, and hypersensitivity. J. Allergy. 25: 168-189.

5. Beall, G. N. 1963. Plasma histamine concentrations in allergic diseases. J. Allergy. 34: 8-15.

6. Kaplan, A. P., L. Gray, R. E. Shaff, Z. Horakova, and M. A. Beaven. 1975. In vivo studies of mediator release in cold urticaria and cholinergic urticaria. J. Allergy Clin. Immunol. 55: 394-402.

7. Soter, N. A., S. I. Wasserman, and K. F. Austen. 1976. Cold urticaria: release into the circulation of histamine and eosinophil chemotactic factor of anaphylaxis during cold challenge. $N$. Engl. J. Med. 294: 687-690.

8. Kent, J. F., and E. H. Fife, Jr. 1963. Precise standardization of reagents for complement fixation.Am.J. Trop. Med. Hyg. 12: 103-116.

9. Borsos, T., and H. J. Rapp. 1963. Chromatographic separation of the first component of complement and its assay on a molecular basis. J. Immunol. 91: 851-858.

10. Ruddy, S., and K. F. Austen. 1967. A stoichiometric assay for the fourth component of complement in whole human serum using EAC1 ${ }^{\mathrm{gp}}$ and functionally pure human second component. J. Immunol. 99: 1162-1172.

11. Ruddy, S., M. R. Klemperer, F. S. Rosen, K. F. Austen, and J. Kumate. 1970. Hereditary deficiency of the second component of complement (C2) in man: correlation of C2 haemolytic activity with immunochemical measurements of C2 protein. Immunology. 18: 943-954.

12. Ruddy, S., and K. F. Austen. 1969. C3 inactivator of man. I. Hemolytic measurement by the inactivation of cellbound C3. J. Immunol. 102: 533-543.

13. Ruddy, S., L. K. Everson, P. H. Schur, and K. F. Austen. 
1971. Hemolytic assay of the ninth complement component: elevation and depletion in rheumatic diseases. J. Exp. Med. 134 (Suppl.): 259-275.

14. Mancini, G., A. O. Carbonara, and J. F. Heremans. 1965. Immunochemical quantitation of antigens by single radial immunodiffusion. Immunochemistry. 2: 235-254.

15. Lewis, E. J., C. B. Carpenter, and P. H. Schur. 1971. Serum complement component levels in human glomerulonephritis. Ann. Intern. Med. 75: 555-560.

16. Ruddy, S., and K. F. Austen. 1970. The complement system in rheumatoid synovitis. I. An analysis of complement component activities in rheumatoid synovial fluids. Arthritis. Rheum. 13: 713-723.

17. Kohler, P. F., and H. J. Müller-Eberhard. 1967. Immunochemical quantitation of the third, fourth, and fifth components of human complement: concentrations in the serum of healthy adults. J. Immunol. 99: 1211-1216.

18. Hunsicker, L. G., S. Ruddy, C. B. Carpenter, P. H. Schur, J. P. Merrill, H. J. Müller-Eberhard, and K. F. Austen. 1972. Metabolism of the third complement component (C3) in nephritis. Involvement of the classic and alternate (properdin) pathways for complement activation. $N$. Engl. J. Med. 287: 835-840.

19. Ruddy, S., D. T. Fearon, and K. F. Austen. 1975. Depressed synovial fluid levels of properdin and properdin factor B in patients with rheumatoid arthritis. Arthritis Rheum. 18: 289-295.

20. Gigli, I., S. Ruddy, and K. F. Austen. 1968. The stoichiometric measurement of the serum inhibitor of the first component of complement by the inhibition of immune hemolysis. J. Immunol. 100: 1154-1164.

21. Soter, N. A., K. F. Austen, and I. Gigli. 1974. The complement system in necrotizing angiitis of the skin. Analysis of complement component activities in serum of patients with concomitant collagen-vascular diseases. $J$. Invest. Dermatol. 63: 219-226.

22. Böyum, A. 1968. Isolation of leukocytes from human blood: further observations. Scand. J. Clin. Lab. Invest. 21 (Suppl. 97): 31-50.

23. Goetzl, E. J., and K. F. Austen. 1972. A neutrophilimmobilizing factor derived from human leukocytes. I. Generation and partial characterization.J. Exp. Med. 136: 1564-1580.

24. Boyden, S. 1962. The chemotactic effect of mixtures of antibody and antigen on polymorphonuclear leukocytes. J. Exp. Med. 115: 453-466.

25. Ward, P. A., and E. L. Becker. 1968. The deactivation of rabbit neutrophils by chemotactic factor and the nature of the activatable esterase. J. Exp. Med. 127: 693-709.

26. Kaplan, A. P., A. B. Kay, and K. F. Austen. 1972. A prealbumin activator of prekallikrein. III. Appearance of chemotactic activity for human neutrophils by the conversion of human prekallikrein to kallikrein. J. Exp. Med. 135: $81-97$.

27. Wasserman, S. I., D. Whitmer, E. J. Goetzl, and K. F. Austen. 1975. Chemotactic deactivation of human eosinophils by the eosinophil chemotactic factor of anaphylaxis. Proc. Soc. Exp. Biol. Med. 148: 301-306.

28. Goetzl, E. J., and K. F. Austen. 1976. Structural determinants of the eosinophil chemotactic activity of the acidic tetrapeptides of eosinophil chemotactic factor of anaphylaxis. J. Exp. Med. 144: 1424-1437.

29. Lewis, R. A., E. J. Goetzl, S. I. Wasserman, F. H. Valone, R. H. Rubin, and K. F. Austen. 1975. The release of four mediators of immediate hypersensitivity from human leukemic basophils. J. Immunol. 114: 87-92.

30. Austen, K. F., S. I. Wasserman, and E. J. Goetzl. 1976. Mast cell-derived mediators: structural and functional diversity and regulation of expression. In Molecular and Biological Aspects of the Acute Allergic Reaction. S. G. O. Johansson, K. Strandberg, and B. Uvnäs, editors. Plenum Publishing Corporation, New York. 293-320.

31. Atkins, P. C., M. Norman, H. Weiner, and B. Zweiman. 1977. Release of neutrophil chemotactic activity during immediate hypersensitivity reactions in humans. Ann. Intern. Med. 86: 415-418.

32. Soter, N. A., M. C. Mihm, I. Gigli, S. C. Johnson, H. F. Dvorak, and K. F. Austen. 1975. Cellular kinetics of cutaneous necrotizing angiitis in a patient with cold urticaria and dermographism. Clin. Res. 23: 386A. (Abstr.)

33. Dolovich, J., F. E. Hargreave, R. Chalmers, K. J. Shier, J. Gauldie, and J. Bienenstock. 1973. Late cutaneous allergic responses in isolated IgE-dependent reactions. J. Allergy Clin. Immunol. 52: 38-46.

34. Solley, G. O., G. J. Gleich, R. E. Jordon, and A. L. Schroeter. 1976. The late phase of the immediate wheal and flare skin reaction. Its dependence upon IgE antibodies. J. Clin. Invest. 58: 408-420. 